Проблеми математичного моделювання та теорії диференціальних рівнянь

УДК $532.5+\mathbf{5 2 3 . 9}$

\title{
ОБЕРНЕНА ЗАДАЧА ПЛАНЕТНИХ ВІДСТАНЕЙ
}

\author{
В. I. Перехрест*, М. М. Осипчук** \\ * Дніпропетровсъкий національний університет ім. Олеся Гончара, \\ Дніпропетровсък 49050. E-mail: prokhrest@i.ua \\ ** Дніпропетровсъкий національний університет ім. Олеся Гончара, \\ Дніпропетровсък 49050. E-mail: Nykolay1111@bigmir.net
}

Розглядається обернена задача планетних відстаней; її постановка полягає в тому, щоб за відомими параметрами руху кількох планет у деякій екзопланетарній системі визначити основні параметри цієї системи та встановити її повну структуру: загальну кількість планет, радіуси їх орбіт та параметри руху. Розроблено чисельно-аналітичні алгоритми розв'язання цієї задачі, які застосовано до ідентифікації двох реальних планетарних систем.

Ключові слова: планетарні системи, планетні відстані, ідентифікація екзопланетарних систем.

\section{1. Вступ. Пряма та обернена задачі планетних відстаней}

У праці [1] на основі вихрової теорії отримано закон планетних відстаней у будь-яких планетарних системах із масивною центральною зіркою та низкою планет. Для Сонячної системи він дає хорошу відповідність з реальними відстанями планет, хоча за формою дещо відрізняється від відомого емпіричного закону Тиціуса - Боде [2]. Точніше, якщо закон Боде має експоненційну форму, то наш закон є близьким до параболи 4-го степеня.

Отже, закон планетних відстаней встановлює залежність між первинними параметрами $\left(r_{i}, \omega_{i}\right)$ руху на центральних колах вихрових кілець планетарного вихору та кінцевими значеннями $\left(R_{i}, \Omega_{i}\right)$ цих параметрів (радіусів та кутових швидкостей) планет у сформованій у полі тяжіння зірки планетарній системі. Ці залежності отримано в [1] у вигляді функцій

$$
\begin{aligned}
& R_{i}=f\left(r_{i}, \omega_{i}, \alpha, C_{0}, C_{2}, M\right), \quad i=1,2, . ., m, \\
& \Omega_{i}=g\left(r_{i}, \omega_{i}, \alpha, C_{0}, C_{2}, M\right),
\end{aligned}
$$

де $\alpha, C_{0}, C_{2}$ - параметри, які визначають структуру й рух первинного вихору, $M$ - маса зірки. Якщо задати значення цих чотирьох параметрів, то формули (1.1) дають однозначну відповідність між двома вихідними змінними $\left(r_{i}, \omega_{i}\right)$ та двома їх функціями $\left(R_{i}, \Omega_{i}\right)$ за $(1.1)$, - це і було зроблено у праці [1]. Порівняння теоретичних значень відстаней 11 планет Сонячної системи з їх

(C) B. I. Перехрест, М. М. Осипчук, 2012 
реальними значеннями показало хорошу відповідність цих величин, особливо для середнього ряду планет.

Велике значення має обернена задача: за заміряними експериментальними значеннями змінних $\left(R_{i}, \Omega_{i}\right)$ для кількох екзопланет знайти основні параметри первинного вихору $\alpha, C_{0}, C_{2}$ даної планетарної системи та визначити обернені залежності

$$
\begin{aligned}
& r_{i}=\bar{f}\left(R_{i}, \Omega_{i}, \alpha, C_{0}, C_{2}, M\right), \\
& \omega_{i}=\bar{g}\left(R_{i}, \Omega_{i}, \alpha, C_{0}, C_{2}, M\right) .
\end{aligned}
$$

Оскільки прямі залежності (1.1) не є простими алгебраїчними, то встановлення обернених залежностей (1.2) зводиться до систем нелінійних рівнянь, що залежать від кількох параметрів. Така задача і є предметом нашого аналізу.

Зокрема, у працях $[3,4]$ показано, що визначальним параметром у цій теорії $€$ параметр $\alpha$ : він визначає кількість $m$ тороїдних вихорів - зародків планет та їх характеристики $\left(r_{i}, \omega_{i}\right)$, за якими можна з прямих залежностей (1.1) обрахувати остаточні положення та параметри руху $\left(R_{i}, \Omega_{i}\right)$ усіх планет нових екзопланетарних систем, у тому числі й ще не відкритих. Це дасть астрономам обгрунтовані підстави для пошуку нових екзопланет, тобто для повної ідентифікації екзопланетарних систем, яких за останне десятиліття відкрито понад 350, і серед них понад 30 мають кілька планет [8].

\section{2. Теорія планетарного вихору і закон планетних відстаней}

Нижче ми подамо основні співвідношення та формули теорії планетарного вихору $[1,4,6]$, побудованої на основі нового окремого розв'язку гідродинамічних рівнянь Ейлера для сферичних вихрових течій [3]. Головною фізичною особливістю цієї осесиметричної просторової течії є наявність у центрі вихрового диполя, який обтікається рухомим закрученим потоком космічного простору, і взаємодія цих рухів породжує вихрову течію планетарного вихору 3 квазіперіодичними хвилями збурення (рис.1) типу хвиль Росбі.

Отже, скористаємось побудованим у праці [3] розв'язком для функції течії $\Psi(r, \theta)$ просторового осесиметричного вихору у сферичній системі координат $(r, \theta, \varphi)$ :

$$
\Psi=C_{2} \Phi(\alpha, y) \sin ^{2} \theta, \Phi(\alpha, y)=\left[\alpha y^{2}+\left(\cos y-\frac{\sin y}{y}\right)\right] .
$$

Через функцію (2.1) поле швидкостей вихрової течії визначається формулами [5]:

$$
V_{r}=-\left(r^{2} \sin \theta\right)^{-1} \frac{\partial \Psi}{\partial \theta}, V_{\theta}=(r \sin \theta)^{-1} \frac{\partial \Psi}{\partial r}, \mathrm{~V}_{\varphi}=\frac{C_{0} \Psi}{r \sin \theta}
$$

У розгорнутому вигляді за формулами $(2.1),(2.2)$ маємо поле швидкостей:

$$
\begin{aligned}
& V_{r}=-2 C_{2} C_{0}^{2} \frac{\Phi(y)}{y^{2}} \cos \theta, \\
& V_{\theta}=C_{2} C_{0}^{2} \frac{\Phi^{\prime}\left(\frac{1}{y}\right)}{y} \sin \theta, \\
& V_{\varphi}=C_{2} C_{0}^{2} \frac{\Phi(y)}{y} \sin \theta .
\end{aligned}
$$


Вище введено безрозмірний радіус $y=C_{0} r$ і параметр $\alpha$, який зрештою визначається [3] через основні параметри течії таким чином:

$$
\alpha=-\frac{V_{\infty}}{2 C_{0}^{2} C_{2}}
$$

де $V_{\infty}$ - поступальна швидкість закрученого простору, $C_{2}-$ довільна стала у розв'язку (2.1), яка виражає момент центрального вихрового диполя; $C_{0}-$ параметр закручування простору, що випливає з формули (2.2).

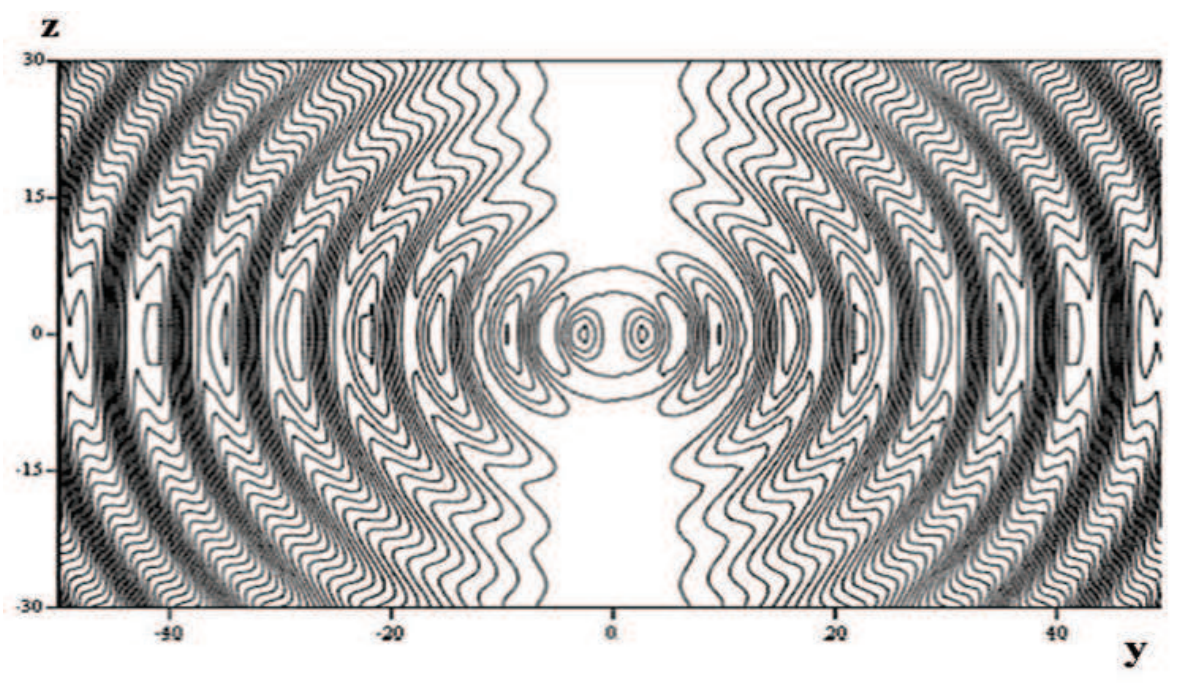

Рис. 1. Загальний вигляд планетарного вихору - меридіональний переріз

Планетарний вихор, зображений на рисунку 1, має два внутрішні тороїдні вихори, що містяться всередині двох нерухомих і непроникних сфер та обертаються у протилежних напрямках. Крім того, у течії існує низка зовнішніх торових кілець - 11, які обертаються в один бік і обтікаються незамкнутими лініями течії. Вихрові зони цих кілець відокремлюються від основної течії петлею сепаратриси - лінії течії, яка має точку самоперетину. Саме такою вихровою структурою доцільно моделювати первинний вихор, що утворив Сонячну систему [6], хоча ця структура не є остаточною і в подальшому може бути уточненою.

Структури $(n, m)$ вихору, тобто кількість внутрішніх $(n)$ та зовнішніх $(m)$ вихорів визначається параметром $\alpha(2.4)$ у розв'язку (1.2). У публікації [6] детально проаналізовано залежність структур $(n, m)$ планетарних вихорів від параметра $\alpha$ та встановлено критичні значення цього параметра, за яких відбуваються біфуркації суміжних вихрових структур. Нижче наведена підсумкова таблиця 1 , яка ставить у відповідність певним проміжкам цього параметра відповідні вихрові структури $(n, m)$. У кожній структурі з першим номером $n$ біфуркація за номером $m$ відбувається при дрібнішому розбитті параметра $\alpha$ і тут не указана, - дивіться [6]. 
Таблиця 1. Інтервали параметра $\alpha$

\begin{tabular}{|c|c|c|}
\hline Інтервали $\alpha$ & $n$ & $m$ \\
\hline $0,01186812676<\alpha<1 / 3$ & 1 & $0-6$ \\
\hline$-0,02872363139<\alpha<-0,006519887466$ & 2 & $2-11$ \\
\hline $0,00412853209<\alpha<0,01186812676$ & 3 & $5-18$ \\
\hline$-0,006519887466<\alpha<-0,0028507108$ & 4 & $10-26$ \\
\hline
\end{tabular}

Радіуси $y_{i}$ центральних кіл вихрових кілець знаходяться як особливі точки векторного поля швидкостей (2.3) [6];точка $y_{i}$ за топологією поля $є$ «центром», але до множини особливих точок поля (2.3), які є коренями рівняння

$$
\Phi^{\prime}(\alpha, y)=0,
$$

входять також сідлові точки, які чергуються 3 «центрами».

На центральних колах вихрових кілець $y=y_{i}$ відбувається рівномірне обертання частинок із кутовою швидкістю $\omega_{i}=V_{\varphi} / r_{i}$, що з урахуванням (2.3) дає

$$
\omega_{i}=C_{2} C_{0}^{2}\left(\alpha+\frac{1}{y_{i}^{2}}\left(\cos y_{i}-\frac{\sin y_{i}}{y_{i}}\right)\right)=C_{2} C_{0}^{3} \frac{\Phi\left(\alpha, y_{i}\right)}{y_{i}^{2}},
$$

на цих же колах і утворюються планети.

Далі зв'яжемо параметри руху $\left(r_{i}, \omega_{i}\right), i=1,2, . ., m$ в первинному вихорі 3 параметрами руху $\left(R_{i}, \Omega_{i}\right)$ планет у сформованій планетарній системі, користуючись для кожного з вихрових кілець законами збереження осьового кінетичного момента

$$
m_{i} \omega_{i} r_{i}^{2}=m_{i} \Omega_{i} R_{i}^{2}, i=1,2, . ., m
$$

та умовою рівноваги обертальної маси $m_{i}$ у полі сили тяжіння зірки масою $M$

$$
\frac{M m_{i}}{R_{i}^{2}} f=m_{i} R_{i} \Omega_{i}^{2}, i=1,2, . ., m
$$

Розв'язання цих двох рівнянь з використанням формул (2.1) та (2.5) дає [1]:

$$
\begin{aligned}
R_{i} & =K_{R} \Phi^{2}\left(\alpha, y_{i}\right), \\
\Omega_{i} & =K_{\Omega} / \Phi^{3}\left(\alpha, y_{i}\right), \quad i=1,2, . ., m,
\end{aligned}
$$

де $M$ - маса зірки, $f=6,67 * 10^{-11}$ нм$^{2} /$ кг $^{2}-$ універсальна гравітаційна стала; $K_{R}=\beta^{2} / f M, K_{\Omega}=(f M)^{2} /(\beta)^{3}, \beta=C_{0} C_{2}$ - числові коефіцієнти.

Отже, остаточні параметри руху планет $\left(R_{i}, \Omega_{i}\right)$ за формулами $(2.8)$ виражено через первинні радіуси центрів кілець $y_{i}$ та параметри вихору $\alpha, C_{0}$, $C_{2}, M$ - це і $є$ прямий закон планетних відстаней. Розрахунок планетних відстаней $R_{i}$ для теоретичного аналога Сонячної системи - планетарного вихора структури $(2,11)$ з параметром $\alpha=-0,00655$ показав хорошу відповідність теоретичних та реальних відстаней планет Сонячної системи [1]. Далі на цій основі поставимо обернену задачу. 


\section{3. Обернена задача планетних відстаней}

Припустимо, що нам відомі хоча б два набори параметрів $\left(R_{i}, \Omega_{i}\right), i=k, k+l$ для двох планет у деякій екзопланетарній системі. Ці планети можуть бути як послідовними (відповідати суміжним вихровим кільцям), так і несуміжними, з пропусками. Окремою задачею $є$ встановлення номерів $k$ та $k+l$ цієї пари, порахованого від зірки, але поки що будемо вважати його відомим.

Поставимо задачу: За даними експериментальними значеннями параметрів руху двох планет $\left(R_{k}, \Omega_{k}\right)$, i $\left(R_{k+1}, \Omega_{k+1}\right)$ знайти параметри $\alpha, C_{0}, C_{2}, M$ первинного вихору системи і визначити: 1$)$ загальну кількість планет у системі; 2) їх планетні відстані $R_{i}$ від зірки; 3) кутові швидкості $\Omega_{i}$ їх обертання навколо зірки.

По-перше, параметр $M$ можна визначити безпосередньо через експериментальні дані з 3-го закону Кеплера:

$$
f M=R_{1}^{3} \Omega_{1}^{2}=R_{2}^{3} \Omega_{2}^{2} .
$$

Не обмежуючи загальності, покладемо $k=1$ і скористаємося рівняннями (2.8), звідки підрахуємо величину питомого кутового момента:

$$
\beta \Phi\left(\alpha, y_{1}\right)=I_{1},
$$

де позначено $I_{1}=\Omega_{1} R_{1}^{2}-$ кутовий момент першої планети. 3 огляду на $(2.1)$ запишемо це рівняння у формі:

$$
\alpha y_{1}^{2}+\cos y_{1}-\frac{\sin y_{1}}{y_{1}}=\frac{I_{1}}{\beta} .
$$

Долучимо до нього ще рівняння $\Phi^{\prime}(\alpha, y)=0$, яке визначає особливі точки центри $y_{1}$ тороїдних кілець через параметр $\alpha$ :

$$
-2 \alpha y_{1}+\sin y_{1}+\frac{1}{y_{1}}\left(\cos y_{1}-\frac{\sin y_{1}}{y_{1}}\right)=0 .
$$

Виключимо із системи рівнянь (3.3), (3.4) параметр $\alpha$ і отримаємо нову систему рівнянь:

$$
\begin{aligned}
& H\left(y_{1}\right) \equiv \frac{\sin y_{1}}{y_{1}}+\frac{1}{y_{1}^{2}}\left(\cos y_{1}-\frac{\sin y_{1}}{y_{1}}\right)=2 \alpha, \\
& G\left(y_{1}\right) \equiv y_{1} \sin y_{1}+3\left(\cos y_{1}-\frac{\sin y_{1}}{y_{1}}\right)=\frac{2 I_{1}}{\beta},
\end{aligned}
$$

у якій рівняння з параметрами $\alpha$ і $\beta$ відокремлені.

Очевидно, що таку ж систему рівнянь ми будемо мати для кожного $i$-го кола вихрового кільця та відповідно $i$-ї планети з $m$ планет системи, у тому числі й для другої у вибраній парі, тобто

$$
H\left(y_{2}\right)=2 \alpha, \quad G\left(y_{2}\right)=2 I_{2} / \beta,
$$

де функції $H$ і $G$ означено вище, (3.5). 
У рівняннях (3.5) та (3.6) параметри $\alpha$ та $\beta$ спільні, а питомі кутові моменти $I_{1}, I_{2}$ визначаються з експериментальних даних $\left(R_{1}, \Omega_{1}\right),\left(R_{2}, \Omega_{2}\right)$ за формулою (3.2). Таким чином, система рівнянь (3.5)-(3.6) є одним із варіантів визначальних рівнянь ідентифікації. Формально з цих чотирьох рівнянь ми визначаємо чотири величини $\left(y_{1}, y_{2}, \alpha, \beta\right)$. Параметр $M$ визначається безпосередньо з рівняння (3.1).

Можна запропонувати кілька варіантів вибору системи визначальних рівнянь для задачі ідентифікації. Наприклад, ми користувалися ще й такою системою рівнянь:

$$
\begin{gathered}
R_{1}-K_{R} \Phi^{2}\left(\alpha, y_{1}\right)=0, \quad R_{2}-K_{R} \Phi^{2}\left(\alpha, y_{2}\right)=0 \\
\Phi^{\prime}\left(\alpha, y_{1}\right)=0, \quad \Phi^{\prime}\left(\alpha, y_{2}\right)=0 \\
f M=R_{1}^{3} \Omega_{1}^{2}, \quad K_{R}=\beta^{2} / f M \\
\beta=I_{1} / \Phi\left(\alpha, y_{1}\right)=I_{2} / \Phi\left(\alpha, y_{2}\right) .
\end{gathered}
$$

Блок із перших чотирьох рівнянь (3.7) зав'язано в ітераційну схему пошуку значень чотирьох змінних $\left(\alpha, K_{R}, y_{1}, y_{2}\right)$, які є коренями цієї нелінійної системи рівнянь за заданих значень радіусів $R_{1}, R_{2}$ планет. При цьому допоміжні співвідношення (3.8) дозволяють потім підрахувати всі інші визначальні параметри системи. Початкове значення $\alpha_{0}$ вибираємо з припущення про вірогідну структуру $(n, m)$ вихору на основі побудованих раніше [6] таблиць відповідності цих структур значенням $\alpha$, - вище подана спрощена таблиця відповідності (табл. 1).

Система (3.7) має ту перевагу, що безпосередньо варіюванням основного параметра $\alpha$ ми практично завжди добиваємось точного збігу двох експериментальних радіусів $R_{1}, R_{2}$ (табл. 2,3$)$ з теоретичними їх значеннями (2.8). До розв'язування системи (3.7) застосовуємо функцію fsolve() в пакеті Mapleвона реалізовуе метод Ньютона для пошуку розв'язків нелінійної системи рівнянь за допомогою спеціального ступінчастого алгоритму. Для реалізації цього алгоритму потрібне виділення проміжків для чотирьох змінних так, щоб на сукупності цих проміжків система (3.7) мала б не більше одного кореня. Зрештою схема виокремлення проміжків для пошуку коренів виглядає так:

$$
\begin{aligned}
& y_{1} \in\left[i \frac{\pi}{4}+2 k \pi ;(i+1) \frac{\pi}{4}+2 k \pi\right], i=0 \ldots 50, \\
& y_{2} \in\left[i \frac{\pi}{4}+2 \pi(k+l+1) ;(i+1) \frac{\pi}{4}+2 \pi(k+l+1)\right], \\
& K_{R} \in[-20 ; 20], \quad \alpha \in[-1 ; 1] \quad k, l=0,1,2, \ldots
\end{aligned}
$$

де $k$ - кількість проміжних коренів типу центр рівняння $\Phi^{\prime}(\alpha, y)=0$ між радіусом останньої непроникної сфери $y^{*}$ та $y_{1} \sim R_{1} ; l$ - кількість центрів кілець між радіусами $y_{1}$ та $y_{2}$. Застосувавши функцію $f$ solve() для (3.7) на кожній сукупності проміжків (3.9) $i=0 . .50$, ми отримаємо масив з 51 елемента, де під кожним елементом знаходиться розв'язок системи $\left\{\alpha^{i}, K_{R}^{i}, y_{1}^{i}, y_{2}^{i}\right\}$ або певний символьний текст (коли система не має розв'язку на даній сукупності відрізків). Далі, за допомогою функції type(numeric), перебираємо поелементно цей масив, і при значенні 'true' зберігаємо ці елементи у наступний масив, 
який вже представляє лише розв'язки системи (3.7) за певних значень $k$ та $l$. Залишилось перевірити, чи $є y_{1}=y_{1}^{i}$ саме $k$-м зовнішнім центром. Для цього беремо до уваги, що перші корені рівняння $\Phi^{\prime}(\alpha, y)=0$ знаходяться у непроникних сферах і є центрами. Визначаємо радіус $y^{*}$ останньої сфери 3 рівняння $\Phi(\alpha, y)=0$, де $\alpha=\alpha^{i}$ беремо з отриманих розв'язків системи $\left\{\alpha^{i}\right.$, $\left.K_{R}^{i}, y_{1}^{i}, y_{2}^{i}\right\}$ у попередньому циклі. За цим радіусом знаходимо останній центр внутрішнього тора $y_{1}^{v}<y^{*}$ і перевіряемо $y_{1}$ на умову: $y_{1}^{i}-\left(y_{1}^{v}+(2 k+1) \pi\right)<$ $\pi / 2$, тобто чи $є$ між $y_{1}^{i}$ та $y_{1}^{v}$ ще $k$ коренів (типу центр) рівняння $\Phi^{\prime}(\alpha, y)=0$. Таким чином з усієї множини розв'язків системи залишається лише один, або жодного, за певних значень $k$ та $l$.

Особливості реалізації алгоритму пошуку значною мірою залежать від властивостей функцій $\Phi(\alpha, y), \Phi^{\prime}(\alpha, y)$. У роботі [6] було показано, що функція $\Phi^{\prime}(\alpha, y) \in$ коливною і при $\alpha \neq 0$ має скінченну множину коренів $\left\{y_{i}\right\}$ $(i=1,2), m$, яким за прямим законом (2.8) відповідають радіуси $\left\{R_{i}\right\}(i=$ $1,2), m$ орбіт планет. Але до множини коренів рівняння (3.7) входять і координати сідлових точок $\left\{y_{i c}\right\}$, які чергуються з радіусами центрів вихрових кілець. При чисельному аналізі сідлові точки вдається відсіяти, використовуючи властивість квазіперіодичності функції $\Phi^{\prime}(\alpha, y)$ з періодом $\Delta \cong 2 \pi$, що реалізує алгоритм подібний до (3.9), де лише функція fsolve() застосовується не до системи (3.7), а до певної коливної функції з указаною періодичністю.

Якщо у ряді експериментальних значень радіусів відкритих планет є суттєві відхилення від монотонності зростання проміжків за кубічним законом [1], то робиться припущення про наявність між сусідніми планетами кількох $(l)$ проміжних планет і відповідних вихрових кілець, починаючи з одного. Для надійного їх визначення використовується вказана вище властивість квазіперіодичності функцій $\Phi(\alpha, y), \Phi^{\prime}(\alpha, y)$ та процедура (3.9).

Порядкові номери двох базових планет із радіусами $R_{1}, R_{2}$ можна вибирати по-різному, що ми також робили при розрахунках. Для точно ідентифікованої системи очевидно, що результат не повинен залежати від вибору цієї пари. Але у розглянутих прикладах точність ідентифікації системи слабо залежала від такого варіювання.

Очевидно, що чим більший набір експериментальних даних, тобто відкритих планет, тим надійнішими будуть гіпотези про структуру й параметри тестованої системи та точність їі ідентифікації. Розглянуті нами реальні екзопланетарні системи мають не менше чотирьох планет - таких є близько 10 [8]. Але порядкові номери цих планет, пораховані від зірки, насправді є невідомими. Тому часто доводиться варіювати порядком $k$ першої планети та вставляти проміжні кільця між ними, як описано вище.

Найкращим наближенням результату ідентифікації ми вибирали таке, у якому сума відносних відхилень розрахованих і реальних відстаней відомих планет є найменшою.

Особливості спостереження планет методами променевих швидкостей і транзитів [7] показують, що першими відкриваються, як правило, найближчі до зірки планети та групи таких планет [8]. Загалом, можна з певністю вважа- 
ти планету першою, якщо її відстань не перевищує 0,05 a.o., хоча $є$ поодинокі відхилення (в системі Gliese 581 радіуси перших двох планет дорівнюють 0,0285 та 0,0406 а.о.). Точніше, відстань 1-ї планети залежить від співвідношення маси зірки $M$ та інтенсивності обертання $C_{0}$ простору в її околі. Відкритими планетами середнього ряду найчастіше $є$ масивні й об'ємні «юпітери», і між планетами першої групи та «юпітером», як правило, наявний значний проміжок, у якому є кілька неспостережених малих планет. Остання обставина ускладнює ідентифікацію через очевидну наявність кількох невідомих проміжних планет. У чисельному експерименті перебиралися кілька варіантів уставлення проміжних планет за параметром $l$, аж поки не досягалася умова мінімальної суми похибок.

У праці [1] показано, що суттєвою особливістю методики побудови прямої послідовності планетних відстаней є вибір (чи визначення) у первинному вихорі точки рівноваги, від якої вихрові кільця під дією сили тяжіння зірки розходяться у різні боки. Для Сонячної системи такою точкою найпевніше треба вибрати центр 5-го кільця, якому відповідає планетоїд Церера з радіусом $R_{5}=4,11 * 10^{11} \mathrm{~m}$.

Точка рівноваги на коловій орбіті у будь-якій зірковій системі визначається рівністю сили тяжіння та відцентрової сили для того кільця первинного вихору, яке залишається незміщеним, тобто для якого $R_{0}=r_{0}, \Omega_{0}=\omega_{0}$. Простими наслідками рівнянь (2.6), (2.7) для параметрів руху центрального кола цього кільця є співвідношення

$$
F_{M}=\frac{I_{0}^{2}}{r_{0}},
$$

де виділено два інваріанти: $F_{M}=f M-$ питома сила тяжіння зірки та кінетичний момент $I_{0}$ планети.

Із формули (3.10) видно, що при збережені кутового момента $I_{0}$ питома гравітаційна сила і радіус рівноважного кільця обернено пропорційні: у разі збільшення сили тяжіння рівноважний радіус зменшується і навпаки. Ця властивість $є$ дуже важливою для аналізу еволюції планетарного вихору в полі тяжіння зірки [1]. Далі з (3.1) та (3.7) знаходимо:

$$
r_{0}=\frac{I_{0}^{2}}{F_{M}}, \quad \omega_{0}=\frac{F_{M}^{2}}{I_{0}^{3}}
$$

- вирази параметрів рівноважного кільця через інваріанти кільця $I$ та зірки $F_{M}$. Останній параметр $C_{0}$, а з ним і точку рівноваги $R_{0}=r_{0}$ можна визначити із рівняння рівноваги сил (2.7) з урахуванням (3.1), (3.2) для базових точок $y_{1}, y_{2} \sim y_{0}$ :

$$
f M=\frac{C_{0} I_{0}^{2}}{y_{0}}, \quad C_{0}=\frac{f M}{\beta^{2} \Phi^{2}\left(y_{0}\right)} y_{0} .
$$

Параметри рівноважного кільця $\left(R_{0}, \Omega_{0}, y_{0}\right)$ можуть як дорівнювати параметрам 1-го чи 2-го з вибраних вище двох кілець, так і відрізнятися від них. 
Далі, знаючи масштабний коефіцієнт $C_{0}$ планетарного вихору (3.12), пов'язаний з переходом від безрозмірних координат до розмірних, знаходимо і рівноважний радіус

$$
R_{0}=\frac{y_{0}}{C_{0}} .
$$

Оскільки пари вихідних $\left(y_{1}, \omega_{1}\right)$ i $\left(y_{2}, \omega_{2}\right)$ та остаточних параметрів $\left(R_{1}\right.$, $\left.\Omega_{1}\right),\left(R_{2}, \Omega_{2}\right)$ при заданому $\alpha \in$ відповідними розв'язками прямих залежностей (2.8), то вони повинні тотожно задовольняти й обернені системи рівнянь (3.7), які є їх наслідками. Така відповідність була перевірена на прикладі Сонячної системи під час вибору пари Юпітер - Сатурн, тобто 6-ї та 7-ї планет, для яких прямий закон планетних відстаней дає добре узгодження теорії 3 експериментом [1].

Справді, вибираючи теоретичні значення радіусів та кутових моментів 6-го та 7-го вихрових кілець, ми отримали нульову похибку у рівняннях (3.6). У разі підстановки реальних значень кутових моментів $I_{1}, I_{2}$ цих планет рівняння $I_{1} G\left(y_{2}\right)-I_{2} G\left(y_{1}\right)=0$ задовольняється 3 точністю $0,04(4 \%)$. Але при цьому прямий закон планетних відстаней дає для Юпітера похибку у відстані $8 \%$ [1], що і породило відповідну похибку у виконанні рівняння (3.6). Цю похибку можна знівелювати подальшим варіюванням параметра $\alpha$. У нашому прикладі ми добилися похибки у 0,0001 при $\alpha=-0,00533$, що відповідає вихровій структурі $(4,13)$ з чотирма внутрішніми та 13 зовнішніми вихорами (рис.2).

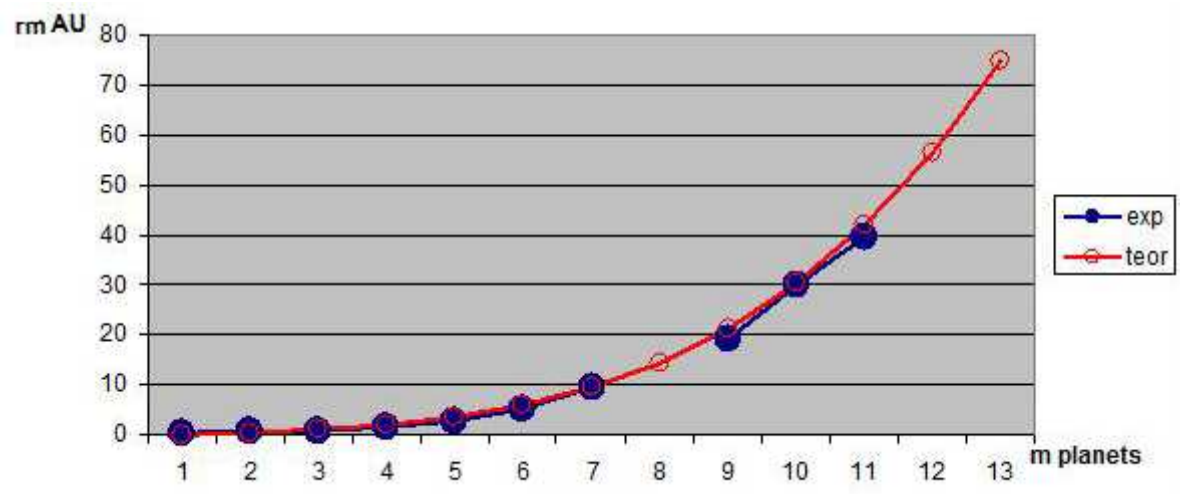

Рис. 2. Ідентифікація планет Сонячної системи: $\alpha=-0,00533$; структура $(n, m)=(4,13)$, -- радіуси відкритих планет; о - радіуси усіх 13 планет

При цьому усі випадкові та систематичні фізичні впливи, не враховані у нашій моделі, очевидно, діятимуть на остаточну величину цього параметра через експериментальні значення кутових моментів $I_{1}, I_{2}$. На жаль, у більшості екзопланетарних систем відкриті $1-3$ планети, як правило, є першими, найближчими до зірки [7], а саме для них прямий закон планетних відстаней дає найбільші похибки [1]. Тому для ефективності розв'язання оберненої зада- 
чі потрібно вдосконалювати методику прямого визначення планетних відстаней з урахуванням найважливіших факторів первинного стану та процесу еволюції вихору до планетарної системи.

Продемонструємо застосування розробленої методики на прикладі ідентифікації планет Сонячної системи (рис. 2, табл. 2), вибравши за базові параметри Землі та Сатурна.

Таблиця 2. Параметри ідентифікації планет Сонячної системи структурою $(4,13), \alpha=$ $-0,00533$

\begin{tabular}{|c|c|c|c|c|}
\hline № пл. & $y_{m}$ & $\left(r_{m}\right)$ teor & $R_{\exp }$ & $\epsilon \%$ \\
\hline 1 & 15,81431 & 0,191911 & 0,39 & $-50,79$ \\
\hline 2 & 22,18503 & 0,460796 & 0,72 & $-36,00$ \\
\hline 3 & 28,54874 & $\mathbf{1}$ & $\mathbf{1}$ & 0,00 \\
\hline 4 & 34,91038 & 1,964384 & 1,52 & $+29,24$ \\
\hline 5 & 41,27221 & 3,547634 & 2,77 & $+28,07$ \\
\hline 6 & 47,63569 & 5,982323 & 5,20 & $+15,04$ \\
\hline 7 & 54,00215 & $\mathbf{9 , 5 4}$ & $\mathbf{9 , 5 4}$ & 0,00 \\
\hline 8 & 60,37304 & 14,53134 & & \\
\hline 9 & 66,75038 & 21,30639 & 19,19 & $+11,03$ \\
\hline 10 & 73,13728 & 30,25491 & 30,07 & $+0,61$ \\
\hline 11 & 79,53950 & 41,80708 & 39,52 & $+5,79$ \\
\hline 12 & 85,97084 & 56,43515 & & \\
\hline 13 & 92,49979 & 74,65956 & & \\
\hline
\end{tabular}

Як бачимо, структура $(4,13)$ є більш адекватною за $(2,11)$, якою раніше ми моделювали Сонячну систему [1]- [6]. Деяка невизначеність залишається тому, що протяжному, від 40 (Плутон) до 100 a.o. зовнішньому астероїдному поясу Койпера може відповідати не одне, а кілька первинних вихрових кілець. У ньому справді відкрито понад 5 великих планетоїдів, і деякі з них, наприклад Еріда, за масою є більшими Плутона.

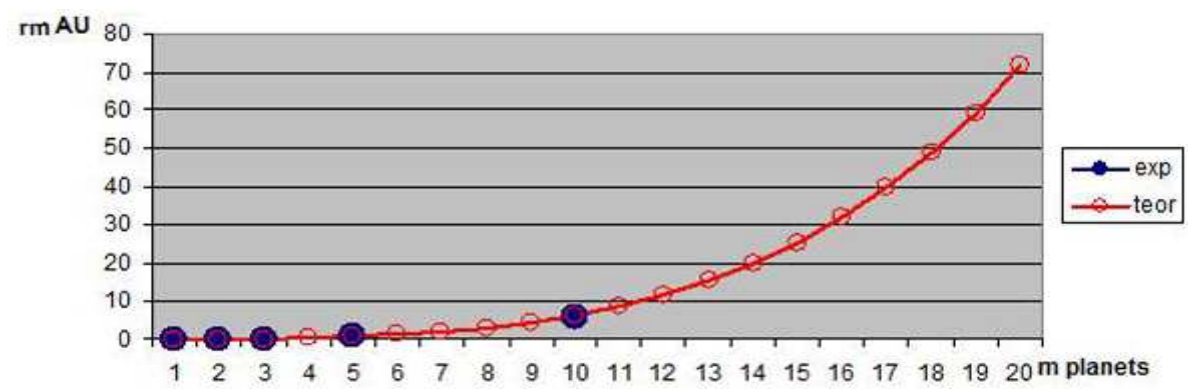

Рис. 3. Ідентифікація планетарної системи 55 Cancri $A$ : $\alpha=-0,00354$; структура $(n, m)=$ $(4,20), \bullet-$ радіуси відкритих планет; о - радіуси усіх 12 планет 
Далі описаний метод було застосовано для ідентифікації екстрасонячної планетарної системи зірки 55 Cancri A, у якій відкрито 5 планет з орбітальними параметрами, взятими з таблиць [8]:

Таблиця 3. Параметри ідентифікації планетарної системи 55 Cancri A структурою $(4,20)$, $\alpha=-0,00354$

\begin{tabular}{|c|c|c|c|c|}
\hline № пл. & $y_{m}$ & $\left(r_{m}\right)$ teor & $R_{\exp }$ & $\epsilon \%$ \\
\hline 1 & 15,756378 & 0,057549 & 0,0384 & $+49,87$ \\
\hline 2 & 22,103197 & 0,121007 & 0,116 & $+4,32$ \\
\hline 3 & 28,442100 & $\mathbf{0 , 2 4 2}$ & $\mathbf{0 , 2 4 2}$ & 0,00 \\
\hline 4 & 34,777726 & 0,451679 & & \\
\hline 5 & 41,111913 & $\mathbf{0 , 7 8 9}$ & $\mathbf{0 , 7 8 9}$ & 0,00 \\
\hline 6 & 47,445585 & 1,300717 & & \\
\hline 7 & 53,779305 & 2,041391 & & \\
\hline 8 & 60,113478 & 3,073388 & & \\
\hline 9 & 66,448445 & 4,466892 & & \\
\hline 10 & 72,784529 & 6,299909 & 5,94 & $+6,06$ \\
\hline 11 & 79,122072 & 8,658280 & & \\
\hline 12 & 85,461464 & 11,63569 & & \\
\hline 13 & 91,803180 & 15,33370 & & \\
\hline 14 & 98,147829 & 19,86177 & & \\
\hline 15 & 104,49624 & 25,33726 & & \\
\hline 16 & 110,84960 & 31,88553 & & \\
\hline 17 & 117,20979 & 39,64003 & & \\
\hline 18 & 123,58003 & 48,74240 & & \\
\hline 19 & 129,96699 & 59,34283 & & \\
\hline 20 & 136,39045 & 71,60094 & & \\
\hline
\end{tabular}

Із таблиці 3 видно, що найкращим варіантом ідентифікації 55 Cancri A виявився вибір як базових 3-ї та 4-ї планет системи, які втім, виявилися не суміжними, а з пропуском однієї невідомої планети.

\section{Висновки}

Розроблена математична модель ідентифікації екзопланетарних систем за параметрами кількох відомих планет складається з кількох блоків процедур адаптивного пошуку, що грунтуються на розв'язуванні скінченних нелінійних систем рівнянь. Показано, що можливі неоднозначності розв'язків задачі можна усунути за допомогою попереднього аналізу експериментальних даних на основі прямого закону планетних відстаней [1] та властивостей визначальної функції $\Phi(\alpha, y)$. Суттєвими для реалізації методики ідентифікації є кілька гіпотез про загальну структуру системи та порядок слідування вибраних двох базових планет у повному ряді планет системи, який заздалегідь невідомий. 
При цьому чим більшим є набір експериментальних даних, тим надійніше й точніше спрацьовує методика ідентифікації.

В усіх прикладах ідентифікації найбільші відносні похибки у відстанях мали порядок $\sim 20-50 \%$ і стосувалися перших двох планет (табл. 2, 3). Це спричиняється малістю самих величин радіусів цих планет. Через це однакові абсолютні похибки для ближніх планет складають відносні похибки $\sim 50 \%$, а для далеких $\sim 10 \%$. Наприклад у системі зірки 55 Cancri $A$ абсолютна похибка для першої планети у 0,02 a.o. становить $49,9 \%$, а похибка у 0,36 a.o. для 10-ї планети складає всього $6 \%$ (табл. 3). Тому критерій оптимальності результату ідентифікації можна видозмінювати за формою.

Ясно, що тривалий, порядку 3 млрд. років, процес еволюції первинного планетарного вихору до розвиненої планетарної системи супроводжувався низкою різноманітних випадкових і систематичних впливів, які не враховано у нашій моделі, але які могли реально вплинути на рух, кінетичні моменти та інші характеристики протопланет. 3 таких впливів можна виділити як суттєві ефекти в'язкості, світловий тиск, співударяння й акрецію, припливні та резонансні взаємодії тощо [2]. Тому годі було б очікувати дуже точного збігу теоретичних та експериментальних даних. 3 огляду на це результати ідентифікації розглянутих у прикладах планетарних систем можна вважати добрими, а саму методику - ефективною.

\section{Бібліографічні посилання}

1. Перехрест В. I. Закон планетних відстаней у вихровій теорії планетарних систем // Вісник Дніпропетр. ун-ту. Серія: Механіка, вип. 15, том 1, 2011, С. 21-33.

2. Алъфвен X. Структура и эволюционная история Солнечной системы // Х. Альфвен, Г. Аррениус - К. : Наукова думка, $1981-332$ с.

3. Перехрест B. I. Новий розв'язок гідродинамічних рівнянь Ейлера для сферичних вихрових течій // В. І. Перехрест, Р. В. Іванов // Вісник Дніпропетр. ун-ту. Серія: Механіка, вип. 6, т. 1, 2002 - С. 60-64.

4. Перехрест В. I. Планетарний вихор та гіпотези Лапласа і Вайцзекера. // Вісник Дніпропетр. ун-ту. Серія: Механіка, вип. 13, т. 2, 2009 - С. 113-124.

5. Милн-Томпсон. Теоретическая гидродинамика.-М., $1964,-655$ с.

6. Перехрест B. I. Про структури планетарних вихорів і закономірності їх обертання // В. I. Перехрест, М. М. Осипчук // Вісник Дніпропетр. ун-ту. Серія: Механіка, вип. 14, т. 1, 2010 - С. 110-118.

7. Mayor M. The search for low-mass planets //Abstract book. XXVII General Assembly of International Astronomical place Union. 3-14 August 2009, CityRio de Janeiro, Brasil - CityplaceRio de Janeiro, 2009, P. 449.

8. http://exoplanets.org/exotable.html 